\title{
The Perception of Biology by Czech Lower Secondary School Students
}

\author{
Jana VIckova ${ }^{1}$, Milan Kubiatko ${ }^{2 *}$, Muhammet Usak ${ }^{3}$ \\ ${ }^{1}$ Masaryk University, Faculty of Education, Department of Education, Porici 31, 60300 Brno, CZECH REPUBLIC \\ 2 University of Zilina, Faculty of Humanities, Univerzitna 1, 01026 Zilina, SLOVAKIA \\ ${ }^{3}$ Kazan Federal University, Kazan, RUSSIA
}

Received 30 November 2018 - Revised 19 February 2019 - Accepted 4 March 2019

\begin{abstract}
Attitudes toward science are more frequently explored than attitudes toward particular science subjects, such as biology. In many countries, however, biology is taught separately from other science subjects. The main aim of this investigation was to detect students' attitudes towards biology, by using a questionnaire as a research tool. Moreover, the partial aims were revelation of influence of gender, residence and grade level on the students' attitudes towards biology. The sample size was created by 363 students from lower secondary schools. The questionnaire (BAQ) consisted of 31 items of Likert type, divided into four dimensions (1. Biology as a school subject; 2 . Informal education; 3. Difficulty and 4. Interest in Biology). In addition, the influence of independent variables was observed in the four dimensions mentioned above. Furthermore, the correlation among dimensions was analyzed as well. Overall score in attitudes toward biology gained by lower secondary school students was neutral. Girls had more positive attitudes toward biology than boys. Mean score according to classes was decreasing with raising of grade level, but without statistically significant effect. More positive attitudes toward biology were revealed among rural students.
\end{abstract}

Keywords: questionnaire, attitudes, biology, lower secondary school students

\section{INTRODUCTION}

Nowadays, pupils and students are often more interested in fields of study like languages, law, economics, etc. These professions seem to be attractive and appreciated by our society. Natural sciences are less popular than humanities, because they are more difficult for students (Christidou 2011; Stuckey et al. 2013). Moreover, to be a scientist is an abstract profession, which means that for pupils and students it is hard to comprehend the purpose of scientific professions. Certainly, science, as well as biology as its part, is an important area of human progress and development, especially biology, which is focused on living organisms, can introduce important findings (e.g. in relation with diseases and their treatment, agriculture, environment, etc.). In order to maintain progress in science or increase human development, it is necessary to guarantee a sufficient amount of university graduates in fields of study that are in demand. Surely, it is necessary to start with motivation in primary schools. When students are interested and motivated in science, they probably will focus on science in their secondary and tertiary education (Sadler 2009).

Below are presented research studies, which are focused on the attitudes students toward biology and authors presented basic research, which are aiming to determination of research aims and research questions.

Prokop, Tuncer and Chuda (2007) conducted research on the topic of middle school students' attitudes toward biology. Results showed positive attitudes toward biology. Students mentioned reasons which improved their attitudes toward biology, specifically contact with living animals and flowers. Biology was more popular among younger students than older ones, and more among girls than boys. Results also showed that students do not consider biology important for their common lives. Approximately three-quarters of students considered biology one of easiest subjects. Particularly students of sixth and ninth grade considered biology an easy subject and

(C) 2019 by the authors; licensee Modestum Ltd., UK. This article is an open access article distributed under the terms and conditions of the Creative Commons Attribution License (http://creativecommons.org/licenses/by/4.0/).

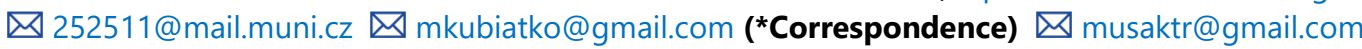




\section{Contribution of this paper to the literature}

- $\quad$ The instrument presented in this study produces valid and reliable results.

- The difference in perception of biology with respect to grade level was not statistically significant.

- Rural students perceived biology significantly positive in comparison with urban students.

students of seventh and eighth grade a more difficult subject. Teachers and their characteristics were found as significant variable. The similar results are possible to find in the study of Prokop, Prokop and Tunniclife (2007). Cipkova et al. (2018) declared positive interest in Biology among majority of students who prefer direct, active participation in the process of knowledge acquisition through the study and exploration of living organisms as well as by the execution and assessment of practicals and experiments.

Another study concentrated on attitudes toward biology and influence of high school students' opinions on biology lessons (Trumper 2006). Author supposed that low quality of biology lessons, and negative perception and opinion on biology lessons, lead to more negative attitudes. In addition, author claimed that students are interested in topics which are connected to their lives (e.g. human body). For this reason author recommended inclusion of students into building the curriculum according to their interests and requirements. The field of opinions on biology lessons and after-school activities gained low score. Results showed that attitudes toward biology are more positive than attitudes toward another science subjects. Girls expressed more positive attitudes toward biology in comparison to boys, while overall attitude toward biology was neutral. The similar results were found out by Zeidan and Jayoshi (2015), where girls had got significantly positive attitudes toward biology in comparison with boys. Authors also found out, students from rural environment had got more positive attitudes in comparison with students from urban environment. It is connected with the proximity of the nature related to rural students. A different study focused on attitudes toward biology of high school students realized in Turkey also showed that the overall attitude was neutral (Ekici \& Hevedanli 2010). Gender was not found statistically significant (but girls reached higher score than boys). Statistically significant differences were revealed among students of first grade and second grade (more positive attitudes showed second grade students) and between first and third grade students (more positive attitudes had first grade students). Attitudes toward biology were not influenced by a primary school where students studied before enrolling in a high school. Study results seemed to be important factor which influences attitudes. Successful students and students with average success had more positive attitudes toward biology than less successful students. More positive attitudes were revealed among students from families with lower average wage. Hussaini, Foong and Kamar (2015) found out similar results as in previous study, the difference in attitudes between males and females was insignificant. Authors also examined the difference in attitudes between science and arts students, the science students achieved statistically significant higher score. It is possible to find some studies, where the sample was created by university students. Also Uitto (2014) did not find out significant difference in the attitudes toward biology between boys and girls. Author found out overall positive attitudes toward biology among students. For example, Hansen and Birol (2014) found out, attitudes of students toward biology become significantly more expert-like from the first year to the fourth year of the program. Similarly, Gardner et al. (2016) found out among nonmajor biology students, that there is significant correlation between perception of biologists as scientists and attitudes toward biology. The similar results were examined in the study of Partin et al. (2011) and Partin and Haney (2012).

\section{PURPOSE OF THE STUDY}

This study contributes to revelation of attitudes toward biology of lower secondary school students. Also, the present study verifies influence of independent variables (gender, residence and grade) to development of attitudes. If attitudes of students and their establishment and variables influencing them are known, they can be improved, and students can be motivated for subsequent education. It is possible to find many studies, which are focused on the problematic of students' attitudes toward biology. The most examined variables are gender and grade level of students. In this study, the residence of respondents is the focus variable, which was examined and it is additional value of the presented study. And also, the research studies from the area of Central Europe about this topic are rare and we are trying to fill the gap, which is in this field of study. The Central Europe is thought in the context of this study as the countries of V4 (Slovakia, Czech Republic, Hungary and Poland). The theoretical background included studies, which were published in the world-known and important scientific databases.

The main aim of the study was to find out attitudes toward biology among lower secondary school students. This aim was developed by partial aims:

1. To find out influence of gender.

2. To determine influence of grade level.

3. To enquire influence of residence. 
Table 1. Distribution of respondents according to demographic items

\begin{tabular}{lll}
\hline Demographic items & & Number of respondents \\
\hline \multirow{2}{*}{ Gender } & Girls & 192 \\
\cline { 2 - 3 } & Boys & 171 \\
\hline \multirow{3}{*}{ Grade level } & 6. & 65 \\
\hline \multirow{2}{*}{ Residence } & 7. & 95 \\
\hline \multirow{3}{*}{ Favourite subject } & 8. & 98 \\
\cline { 2 - 3 } & 9. & 105 \\
\cline { 2 - 3 } & Urban students & 207 \\
\hline Rural students & 156 \\
\hline & Unknown & 113 \\
\cline { 2 - 3 } & Humanities & 60 \\
\cline { 2 - 3 } & Science subjects & 57 \\
\cline { 2 - 3 } & Technical subject & 34 \\
\cline { 2 - 3 } & Art and physical & 99 \\
\hline
\end{tabular}

The research questions were established on the base of partial aims. The research questions were following:

1. Does the gender influence students' attitudes to biology?

2. Are attitudes to biology influenced by grade level?

3. Is there any difference between attitudes of rural and urban students?

\section{METHODS}

\section{Research Tool}

Research tool was questionnaire called Biology Attitudes Questionnaire (BAQ) consisting of two parts. First, there were demographic items (gender, residence, grade level and favourite subject). Second part concentrated on attitudes toward biology, and it included 5-scale Likert type items. The authors of the research were inspired of the other studies, where instrument regarding to attitudes toward biology was used (Prokop, Prokop \& Tunnicliffe 2007), some of the items were used with the permission of authors and some of the items were new. This was the reason why the pilot study was realized. Research tool was verified in the pilot study. According to the results of the pilot research and according results of confirm factor analysis, research tool was adjusted. First version of questionnaire included 39 items from which 8 items were eliminated in total (see subchapter "Data analysis"). Finally, second part of research tool consisted of 31 items. Overall, 18 items were constructed in positive meaning and 13 items in negative meaning. These 31 items were divided into 4 dimensions (detailed information is presented in subchapter "Data analysis").

\section{Respondents}

In total, 363 respondents from 5 lower secondary schools answered the questionnaire. The schools were traditional without any alternative form of education. The non-probability methods of sampling were used, but the sample size was appropriate to use statistical methods and to suggest the conclusions. The age of respondents was between 11 - 16 years. Distribution of respondents according to demographic items is presented in Table 1.

\section{Data Analysis}

Research tool was administered to five lower secondary schools, specifically, three of them were situated in a city and two of them were situated in a village. In this place is needed to write, in case of schools in the urban schools (cities > 5.000 inhabitants) - then village mentioned later should be less than 5.000 inhabitants. In case of schools in the city, authors of this paper administered research tool. In case of the village schools, research tool was administered by teachers, who were instructed about method of assignation of research tool to students. All respondents were informed about anonymity of the research. Students had unlimited time for completing the questionnaire, however, completing the research questions took from 10 to 20 minutes.

Demographic items were determined as independent variables for data analysis. Contrarily, second part of the research tool consisting of Likert type items was determined as dependent variable. Items with positive meaning were coded from 1 (absolutely disagree) to 5 (absolutely agree), items in negative meaning were coded reversely. Lower score reached in questionnaire indicated negative attitudes, higher score indicated positive attitudes. 


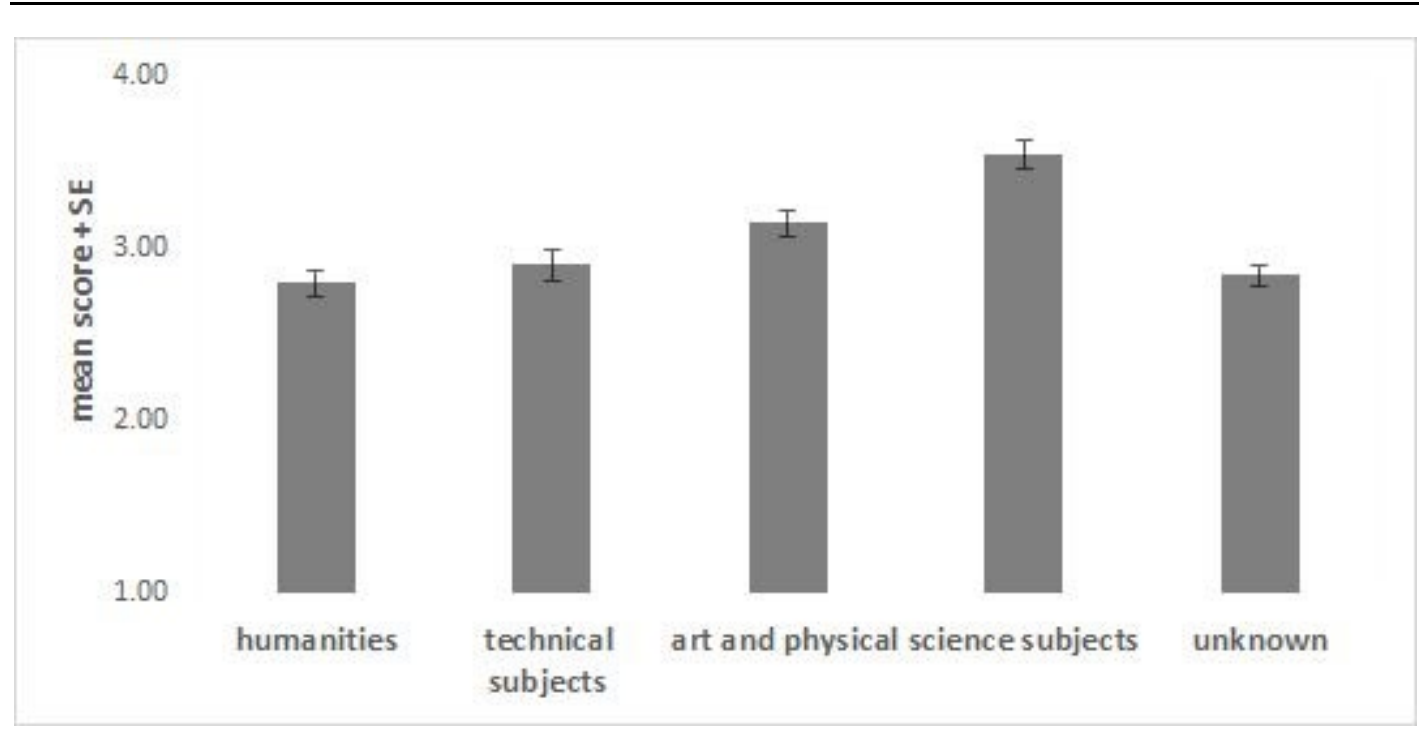

Figure 1. Attitudes toward biology with respect to favourite subject

Reliability of research tool was determined by using Cronbach alpha ( $\alpha=0.92)$, which indicated high reliability of the research tool (Nunnally 1987). Reliability was ascertained for all dimensions separately, and results indicated reliability ranged between 0.54 and 0.92 . Besides, content validity was determined by verifying influence of favourite subject on attitudes toward biology. Statistically significant difference was determined in independent variable favourite subject (score reached in humanities: 2.80, technical subjects 2.91, art and physical 3.15 and science subject 3.55). These findings contributed to the validity of research tool. Figure 1 presents reached score according to favourite subject.

Kolmogor-Smirnov test was applicated for verifying suitability of statistic methods, its results indicated normal distribution of data $(d=0.04 ; p>0.20)$. These results allowed to apply parametric statistic methods.

Confirmatory factor analysis was used for substantiating distribution of items into dimensions and also for verifying appropriateness of items. Research tool was rearranged to better utilisation for identification of attitudes toward biology of lower secondary school students on the base of results of this test. Appropriateness of factor analysis was determined by Kaiser-Meyer-Olkin test and Bartlett test of sphericity. Result of KMO test was 0.93 and result of Bartlett test was $\chi^{2}=6097.27 ; p<0.001$. These results indicated aptness of factor analysis.

Data in numeric form were examined by confirmatory factor analysis with Varimax rotation, which ascertained 4 dimensions with eigenvalue higher than 1.00. Results of factor analysis are provided in Table 2. First dimension was 'Biology as a school subject' and there were 15 items, for instance item number 19 was included in this dimension (I am looking forward to biology lessons). Second dimension included 9 items and it was labelled as 'Informal education.' An example of this dimension is item number 23 (I enjoy biology films on TV). Thirdly, dimension 'Difficulty' was established. This dimension contained 4 items, and example of this dimension is item number 13 (Biology lessons are demanding for me). Last dimension was 'Interest' and there were 3 items, for instance item number 37 (We do not use any tools during biology lessons). These dimensions explained $45.16 \%$ of overall variance, more specifically, majority of it was explained by dimension 1 (23.53 \%). The distribution of items into dimensions was supported by the previous results published in research studies (Prokop, Prokop \& Tunnicliffe 2007; Prokop, Tuncer \& Chuda 2007) and the distribution of items into dimension was confirmed by the results of exploratory factor analysis. In total, 8 items were deleted from final version of research tool. The criterion for the elimination of 8 items was value of factor loading score, the margin value was 0.40 , which is suggested value for the elimination of items (Velicer \& Fava 1998). 
Table 2. Results of factor analysis

\begin{tabular}{|c|c|c|c|c|c|}
\hline & $\alpha$ & I. & II. & III. & IV. \\
\hline (I) Biology as a school subject & 0.92 & & & & \\
\hline (1) Biology is more interesting than other school subjects. & & 0.63 & 0.29 & 0.03 & 0.11 \\
\hline (2) I prefer biology than other subject. & & 0.69 & 0.27 & -0.05 & -0.03 \\
\hline (5) I do not enjoy biology lessons. ${ }^{*}$ & & 0.65 & 0.18 & 0.14 & 0.20 \\
\hline (8) I would like to have biology lessons often as possible. & & 0.60 & 0.28 & -0.01 & 0.01 \\
\hline (9) I am bored during biology lessons. ${ }^{*}$ & & 0.64 & 0.25 & 0.05 & 0.29 \\
\hline (10) I would like to teach biology after my studies. & & 0.48 & 0.34 & -0.01 & 0.00 \\
\hline (19) I am looking forward to biology lessons. & & 0.71 & 0.39 & -0.02 & 0.16 \\
\hline (22) I do not like our biology teacher.* & & 0.59 & -0.05 & 0.06 & 0.33 \\
\hline (26) Biology is interesting for me only because of our teacher. & & 0.54 & -0.04 & -0.16 & 0.05 \\
\hline (29) Biology is unfamiliar for me. ${ }^{*}$ & & 0.63 & 0.24 & 0.22 & 0.25 \\
\hline (30) I do not like reading of science books. ${ }^{*}$ & & 0.57 & 0.19 & 0.12 & 0.07 \\
\hline (31) Biology lessons are entertaining for me. & & 0.66 & 0.32 & -0.09 & 0.17 \\
\hline (33) When I hear word "biology" I have feelings of disgust. ${ }^{*}$ & & 0.73 & 0.10 & 0.20 & 0.06 \\
\hline (35) I hate biology lessons. ${ }^{*}$ & & 0.76 & 0.23 & 0.14 & 0.15 \\
\hline (38) Biology is needless school subject.* & & 0.65 & 0.25 & 0.15 & 0.31 \\
\hline (II) Informal education & 0.82 & & & & \\
\hline (11) I would like to make experiments connected with biology at home. & & 0.19 & 0.61 & 0.09 & 0.16 \\
\hline (12) I would like to take care about animals on farm. & & 0.14 & 0.63 & -0.03 & 0.11 \\
\hline (17) I enjoy picking some stones. & & 0.14 & 0.58 & 0.11 & 0.15 \\
\hline (18) I would like to know how to make milk products (e.g. cheese). & & 0.19 & 0.58 & -0.06 & 0.13 \\
\hline (23) I enjoy biology films on TV. & & 0.20 & 0.67 & 0.09 & 0.03 \\
\hline (24) Visiting of museum is one of my favourite activities. & & 0.18 & 0.69 & 0.00 & -0.08 \\
\hline (25) I like going to the Zoo. & & 0.17 & 0.57 & 0.03 & 0.02 \\
\hline (28) I like picking of mushrooms in nature. & & 0.22 & 0.56 & 0.11 & 0.09 \\
\hline $\begin{array}{l}\text { (36) Knowledge about nature is important for understanding of other } \\
\text { subjects. }\end{array}$ & & 0.17 & 0.46 & 0.08 & 0.32 \\
\hline (III) Difficulty & 0.54 & & & & \\
\hline (4) Biology is just very little useful for society. ${ }^{*}$ & & 0.21 & 0.10 & 0.47 & 0.31 \\
\hline (13) Biology lessons are demanding for me. ${ }^{*}$ & & 0.36 & 0.20 & 0.50 & 0.01 \\
\hline (16) I have to try a lot to understand to biology. ${ }^{*}$ & & 0.27 & -0.08 & 0.63 & -0.17 \\
\hline (32) I feel pressure during biology lessons. ${ }^{*}$ & & -0.06 & -0.06 & 0.59 & -0.06 \\
\hline (IV) Interest & 0.60 & & & & \\
\hline (14) We use a lot of interesting tools during biology lessons. & & 0.33 & 0.20 & -0.23 & 0.59 \\
\hline $\begin{array}{l}\text { (21) Working with living organisms during biology lessons is very } \\
\text { interesting. }\end{array}$ & & 0.18 & 0.42 & -0.14 & 0.57 \\
\hline (37) We do not use any tools during biology lessons. ${ }^{*}$ & & 0.33 & -0.13 & 0.00 & 0.50 \\
\hline eigenvalue & & 7.00 & 5.20 & 1.97 & 2.94 \\
\hline variance (\%) & & 29.08 & 14.13 & 7.05 & 4.08 \\
\hline \multicolumn{6}{|l|}{ Deleted items } \\
\hline (3) Biology can be useful for finding cure against diseases (e.g. cancer). & & 0.08 & 0.30 & 0.07 & 0.38 \\
\hline (6) We should believe everything what scientists said. & & 0.20 & 0.30 & -0.20 & 0.20 \\
\hline (7) Biology decrease my understanding to nature. ${ }^{*}$ & & 0.24 & 0.13 & 0.43 & 0.40 \\
\hline (15) Our teacher explains biology in interesting way. & & 0.46 & 0.19 & -0.17 & 0.49 \\
\hline (20) I like biology experiments. & & 0.12 & 0.57 & -0.02 & 0.46 \\
\hline (27) Biology experiments help me to develop my abilities. & & 0.26 & 0.46 & 0.00 & 0.51 \\
\hline (34) I am feeling nervous during biology experiments. ${ }^{*}$ & & 0.04 & 0.06 & 0.40 & -0.07 \\
\hline (39) I always learn a lot of interesting things during biology lessons. & & 0.37 & 0.08 & -0.07 & -0.37 \\
\hline
\end{tabular}
numbers are identical with numbers in the original version of $\mathrm{BAQ}$

* items coded in reverse order

For determining statistical significant differences according to independent variables were used tests of inductive statistics, especially analysis of variance (ANOVA) was applied. Demographic items were considered to be independent variables and Likert type items were considered to be dependent variables. Pair-wise comparisons were made with Fisher LSD post-hoc test. Relationships among dimensions were ascertained by Pearson's correlational coefficient. The Cohen's d was used for the determination of the effect size. 
3.50

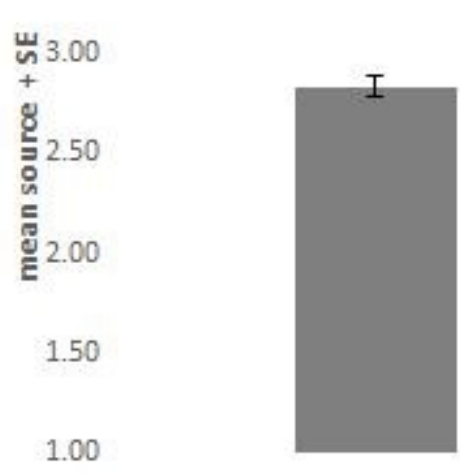

boys

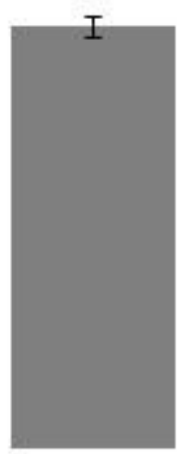

girls

Figure 2. Attitudes to biology with respect toward gender

Table 3. Mean score and standard errors according to independent variables

\begin{tabular}{llll}
\hline Independent variable & & Mean score & Standard error \\
\hline \multirow{2}{*}{ Gender } & Boys & 2.83 & 0.06 \\
\cline { 2 - 4 } & Girls & 3.12 & 0.05 \\
\hline \multirow{3}{*}{ Grade level } & 6. & 3.26 & 0.09 \\
\cline { 2 - 4 } & 7. & 3.07 & 0.07 \\
\hline \multirow{2}{*}{ Residence } & 8. & 2.96 & 0.07 \\
\cline { 2 - 4 } & 9. & 2.74 & 0.07 \\
\hline
\end{tabular}

\section{RESULTS}

Overall attitude score $(x=2.98)$ indicated neutral attitude of students toward biology. Statistically significant difference in attitudes toward biology was discovered between girls and boys $(F=8.13, p<0.05, d=0.92)$. Results showed that girls had more positive attitudes than boys (Figure 2). Mean score and standard errors are presented in Table 3.

Analysis of variance revealed statistically significant difference in case of independent variable grade $(\mathrm{F}=6.14$, $\mathrm{p}<0.05, \mathrm{~d}=1.11$ ). Fishers' LSD post-hoc test uncovered more positive attitudes of students of sixth grade in comparison with students of eighth and ninth grade. Next, results showed more positive attitudes of students of seventh grade than students of ninth grade. Statistically significant difference was uncovered between students of eighth and ninth grade, specifically younger students had more positive attitudes. The highest score gained students of sixth grade, on the contrary students of ninth grade gained the lowest score. These results are provided on Figure 3. Gained mean score and standard errors are presented in Table 3. 


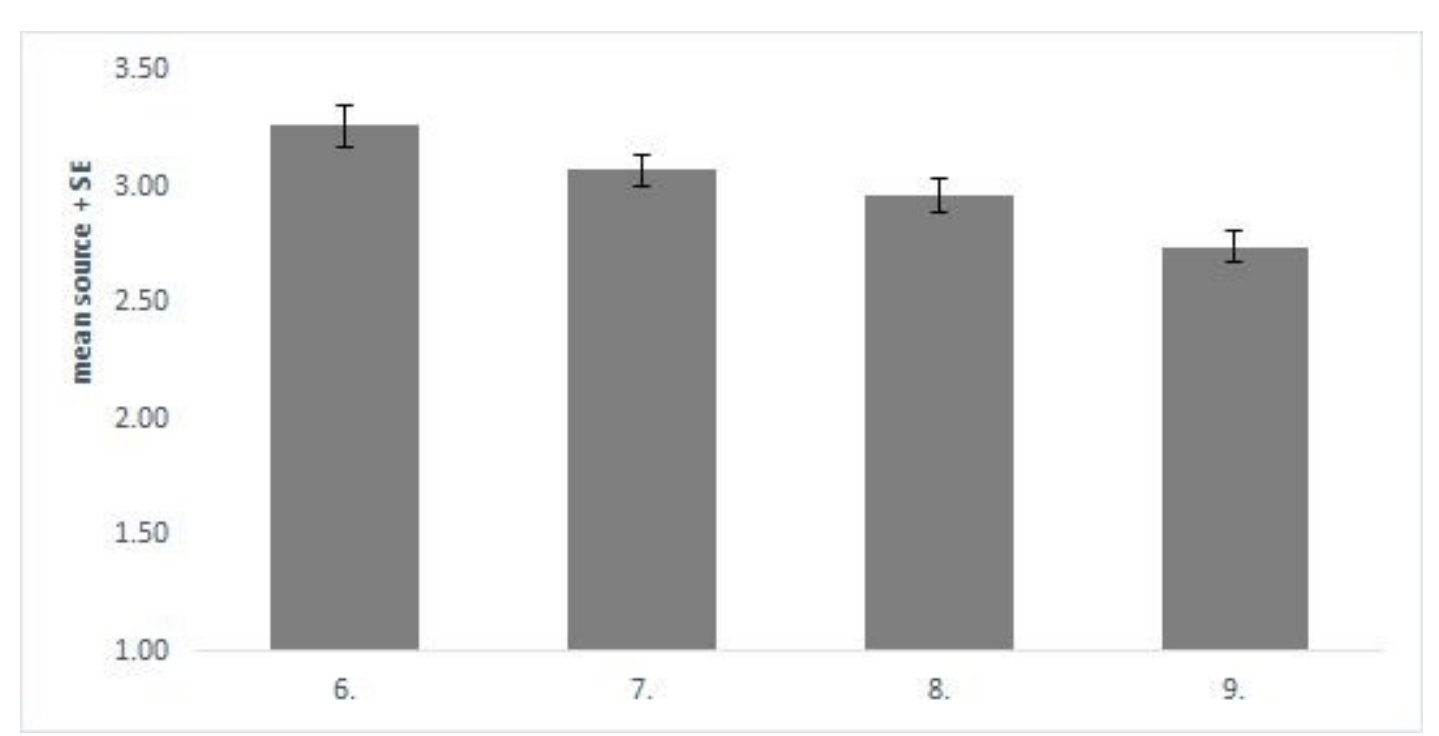

Figure 3. Attitudes toward biology with respect to grade level

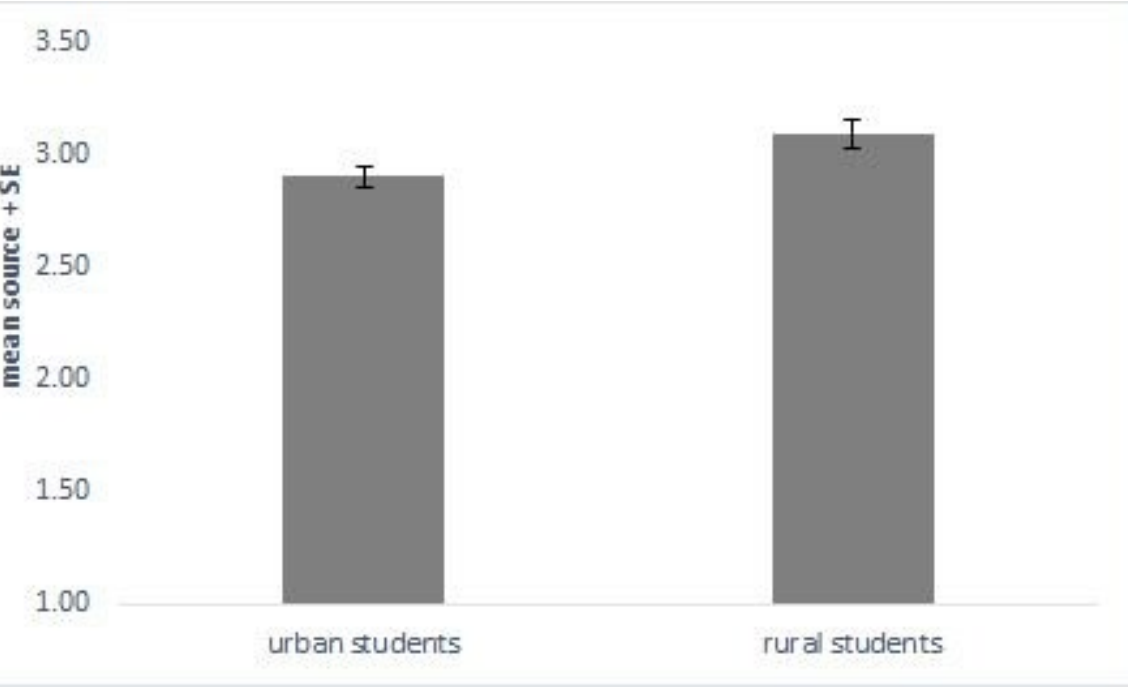

Figure 4. Attitudes toward biology with respect to residence

Table 4. Mean score according to dimensions

\begin{tabular}{lcc}
\hline & Mean score & Standard error \\
\hline Biology as a school subject & 2.84 & 0.91 \\
\hline Informal education & 2.96 & 0.92 \\
\hline Difficulty & 3.37 & 0.82 \\
\hline Interest & 3.22 & 1.03 \\
\hline
\end{tabular}

The statistically significant influence of residence on attitudes toward biology was examined $(\mathrm{F}=7.24, \mathrm{p}<0.05$, $\mathrm{d}=0.89$ ). Rural students expressed more positive attitudes than urban students (Figure 4). Gained mean score and standard errors according to residence are provided in Table 3.

\section{Influence of Independent Variables According to Dimensions}

Influence of independent variables was explored according to dimensions. Mean score and standard errors of each dimension are provided in Table 4 . Detailed results, more specifically mean score and standard errors of independent variables according to each dimension are presented in Table 5. 
Table 5. Mean score and standard errors of independent variables according to dimensions

\begin{tabular}{|c|c|c|c|c|c|c|c|c|c|}
\hline & & \multicolumn{2}{|c|}{ Residence } & \multicolumn{4}{|c|}{ Grade level } & \multicolumn{2}{|c|}{ Gender } \\
\hline & & $\mathbf{u}$ & $\mathbf{r}$ & 6. & 7. & 8. & 9. & b & g \\
\hline \multirow{2}{*}{ Biology as a school subject } & Mean score & 2.75 & 2.97 & 3.19 & 2.90 & 2.83 & 2.59 & 2.70 & 2.97 \\
\hline & Standard error & 0.06 & 0.07 & 0.11 & 0.09 & 0.09 & 0.09 & 0.07 & 0.07 \\
\hline \multirow{2}{*}{ Informal education } & Mean score & 2.89 & 3.05 & 3.23 & 3.17 & 2.89 & 2.65 & 2.77 & 3.12 \\
\hline & Standard error & 0.06 & 0.07 & 0.11 & 0.09 & 0.09 & 0.09 & 0.07 & 0.06 \\
\hline \multirow{2}{*}{ Difficulty } & Mean score & 3.32 & 3.45 & 3.32 & 3.23 & 3.53 & 3.39 & 3.27 & 3.46 \\
\hline & Standard error & 0.06 & 0.07 & 0.10 & 0.08 & 0.08 & 0.08 & 0.06 & 0.06 \\
\hline \multirow{2}{*}{ Interest } & Mean score & 3.12 & 3.36 & 3.67 & 3.40 & 3.08 & 2.92 & 3.06 & 3.36 \\
\hline & Standard error & 0.07 & 0.08 & 0.12 & 0.10 & 0.10 & 0.10 & 0.08 & 0.07 \\
\hline
\end{tabular}

$\mathrm{c}$ - urban students; $\mathrm{r}$ - rural students; $\mathrm{b}$ - boys; $\mathrm{g}$ - girls

Table 6. Relationship among dimensions

\begin{tabular}{lccc}
\hline & \multicolumn{1}{c}{ Informal education } & Difficulty & Interest \\
\hline Biology as a school subject & $0.58^{*}$ & $0.39^{*}$ & $0.52^{*}$ \\
\hline Informal education & & $0.20^{*}$ & $0.42^{*}$ \\
\hline Difficulty & & & 0.07 \\
\hline
\end{tabular}

${ }^{*} p<0.05$

In first dimension 'Biology as a school subject' statistically significant differences were affirmed in all independent variables. More positive attitudes toward biology expressed rural students than urban students $(\mathrm{F}=$ 5.64, $\mathrm{p}<0.05, \mathrm{~d}=0.84)$. Further, girls showed more positive attitudes than boys $(\mathrm{F}=8.38, \mathrm{p}<0.05)$. Finally, Fishers' LSD post-hoc test revealed significant differences between students of sixth grade and students of all other grades, also significant difference was between students of seventh grade and students of ninth grade level $(\mathrm{F}=6.14, \mathrm{p}<$ $0.05, \mathrm{~d}=0.86$ ).

Turning now to second dimension 'Informal education' analysis of variance detected statistically significant differences according to independent variable gender $(F=14.14, p<0.05, d=1.02)$ and grade $(F=8.32, p<0.05, d$ $=1.14$ ). In particular, girls had more positive attitudes than boys. Further, significant differences were revealed between students of sixth grade and students of eighth and ninth grade. Next, significant difference was detected between students of seventh grade and students of eighth and ninth grade. Each of these results showed more positive attitudes of younger students. Residence of students was explored to be statistically significant variable in this dimension $(\mathrm{F}=2.84, \mathrm{p}<0.05, \mathrm{~d}=0.91)$.

Regarding to third dimension 'Difficulty' independent variable gender was determined to be statistically significant $(F=5.04, p<0.05 ; d=0.98)$. Girls showed more positive attitudes. Independent variables residence $(F=$ 2.37, $\mathrm{p}=0.12, \mathrm{~d}=0.91)$ and grade level $(\mathrm{F}=2.29, \mathrm{p}=0.08 ; \mathrm{d}=1.13)$ did not have significant influence on attitudes toward biology.

In terms of dimension 'Interest' all independent variables were statistically significant. Specifically, analysis of influence of variable residence $(\mathrm{F}=4.92, \mathrm{p}<0.05, \mathrm{~d}=0.95)$ revealed more positive attitudes of rural students than urban students. Focusing on variable gender $(\mathrm{F}=8.01, \mathrm{p}<0.05, \mathrm{~d}=0.89)$ girls showed more positive attitudes than boys. Further, Fishers' LSD post-hoc test was applicate on variable grade $(F=9.12, p<0.05, d=1.06)$ and results showed more positive attitudes of sixth grade students in comparison with eighth and ninth grade students. Also, students of seventh grade showed more positive attitudes than students of eighth and ninth grade.

\section{Relationships between Dimensions}

Influence of each dimension to other dimensions was determined as well. Apart from dimension 'Difficulty' and dimension 'Interest' there was identified positive influence of all dimensions mutually. Results of Pearson's relationships coefficient are provided in Table 6. The most positive correlation to other dimensions expressed dimension 'Biology as a school subject'. The strongest relationship was discovered between dimensions 'Biology as a school subject' and 'Informal education'. Further, Pearson's relationships coefficient ascertained relationship between dimensions 'Biology as a school subject' and dimension 'Interest'. As for relationship of dimensions 'Informal education' and 'Interest' there was detected weaker relationship between them. Detailed results of relationship among dimension are presented in Table 6. 


\section{DISCUSSION}

This study was concerning on attitudes determination of lower secondary school students toward biology. Overall score in attitudes toward biology gained by lower secondary school students was neutral. Similar results discovered on high school students Trumper (2006) and Ekici and Hevedanli (2010), furthermore Usak et al. (2009a, b) identified neutral attitudes toward biology on his study conducted on university students. Conversely, positive attitudes toward biology were identified in research conducted on primary schools by Prokop, Tuncer \& Chuda (2007). Although, attitudes toward biology are not always positive, negative attitudes were not identified in none of the studies mentioned above. Curriculum of biology include a huge range of study stuff, abiotic nature on the one side, across microorganisms and bacteria, continuing with flowers and animals, and biology of human on the other side. On the one hand, biology during solving its problems needs synthesis and gathering information from various fields of science together (for instance solving problems connected with ecosystems). On the other hand, biology analyse phenomenon and processes to gain profound information (for instance genetics). This huge range of stuff included into biology allow to both pupils and students choose personally interesting and favourable topics, unfortunately the same reason leads to possibility to choose personally tedious and unpopular topics. Therefore, neutral attitudes toward biology can appear often.

Girls had more positive attitudes toward biology than boys. This result is consistent with results of study conducted on lower secondary schools by Prokop, Prokop and Tunnicliffe (2007) and also Prokop, Tuncer and Chuda (2007). Besides, some previous studies conducted on high schools are in line with this result (specifically, Trumper 2006; Zeidan 2010). Although, this result differs from some published studies on high schools (especially, Ekici \& Hevedanli 2010) and on universities (especially, Usak et al. 2009b) where gender was not identified as statistically significant variable for influencing attitudes toward biology. Altogether, it can therefore be assumed that gender is important factor for attitudes toward biology. Some authors attempted to explain reasons for arising of differences in attitudes toward biology between girls and boys. Baker and Leary (1995) declared assumption that girls like biology quite a lot, in contrast their surroundings do not consider science subjects as appropriate for girls and their employment in future and this can subsequently leads toward more negative attitudes to biology. Moreover, authors described more negative attitudes of girls toward physic and chemistry in comparison with biology. According to these authors, a possible explanation for this might be that girls cannot see in this less favourable subject connection with human body and taking care about other people which is interesting and appealing for girls. Girls had opposite point of view in biology, this lead toward more positive attitudes of girls than boys, who consider different topics of science subjects to be interesting. Jones, Howe and Rua (2000) ascertained differences between boys and girls in attitudes according to activities practised in biology lessons. Boys fulfil experiments with bacteria or chemicals, oppositely girls preferred activities connected with taking care about human body (these activities are more typical for biology than chemistry or physics).

Second research question was focused on the change of attitudes toward biology with respect to grade level of students. Mean score according to classes was really decreasing with raising of grade level. But these changes were not statistically significant so often. More positive attitudes among younger students detected Prokop, Prokop and Tunnicliffe (2007) and also Prokop, Tuncer and Chuda (2007). Trumper (2006) claimed that students showed bigger interest in relation with topics closed to their lives (e.g. human biology). This topic is taught in eighth grade in country, where this study was conducted. It seems that students of eighth grade in our study will show more positive attitudes toward biology than other grade levels. This statement was not confirmed. Students of eighth level gained higher score just than students of ninth grade. Nonetheless, authors conducted research on secondary schools, where concentration of students is more specific. The lowest score was identified among students of ninth grade, which is probably caused by unattractive topic inanimate nature. Result can be influenced by close end of students' studies on lower secondary school and making decision about future studies. In this case, students can consider biology to be less important than other subjects. Contrarily, highest score reached students of sixth grade level (there was statistically significant difference compared to higher grade levels). This result can be caused by more playful education style on lower grade levels.

Third research question was regarding to find out difference in attitudes toward biology with respect to residence of respondents. More positive attitudes toward biology were revealed among rural students. Zeidan (2010) ascertained influence of residence on attitudes toward biology. His results did not revealed statistically significant influence of this independent variable. The similar results were examined by the Babu and Govindharajan (2014). Zeidan and Jayoshi (2015) found out statistically better attitudes toward biology among rural students; this result is in concordance with our findings. The biology curriculum consists of topics such as Botany, Zoology, Ecology and others, which are connected with the environment and it can cause higher interest about the biology as subject and it is connected with better attitudes toward biology. The similar statement is possible to find in the study of Ihuoma (2017).

Influence of independent variable was examined for dimensions. Important factor changing attitudes toward biology was gender. Girls showed more positive attitudes toward biology in overall result and in all four 
dimensions. Statistically significant influence on dimensions showed independent variable residence. Statistically significant differences were detected among all dimensions except "Difficulty". Influence of class according to dimensions I overall score revealed differences between students of sixth grade level and eighth grade level, next between students of sixth grade level and ninth grade level. Difference according to grade level was not detected only in dimension "Difficulty".

Individual dimensions usually correlated positively. The strongest relationship was between dimensions "Biology as a school subject" and "Informal education". It seems obvious that students concerning on activities connected with biology in their leisure time percept biology lesson more positive. Strong relationship was detected between dimensions "Biology as school subject" and "Interest". These results indicated that huger interest in biology, bigger concern in biology lessons. Dimensions "Informal education" and "Interest" correlated positively too. If students practice activities connected with biology in their leisure time, they express bigger interest toward biology. Next, positive correlation was between dimensions "Biology as a school subject" and "Difficulty". Increasing difficulty in biology leads to more negative perception of biology. If teachers do not relieve biology lessons by interesting things, videos and other less demanding activities, than students will consider biology more difficulty. Moreover, dimensions "Informal education" and "Difficulty" collated positively. More activities in leisure time connected with biology, less difficult point of view on biology lessons. From all results arise eminent influence of difficulty on attitudes toward biology.

\section{CONCLUSION}

On the basis of results, there are some areas, which could be adapted in the learning process of biology and they could influence students' attitudes toward biology in the positive way.

Modern technologies are more frequent in school lessons nowadays. Its influence on biology education and attitudes toward biology was not acquired in our study. Kara and Yesilyurt (2007) on base of their results claim that students taught by modern technologies showed more positive attitudes toward biology. These students also gained better results in the test focusing on misconceptions in particular part of biology. Movahedzadeh (2011) on base of results of his study recommended school subject taught by e-learning. Students using e-learning express more contentment and they reached better results. Studies mentioned above were conducted on higher levels of education. Similar results can be expected on primary school too. PCs, tablets, interactive boards and other modern technologies are more frequent nowadays in common life. Students have to learn how effectively use these tools. If using of these tools lead to better, more effective, more interesting education or positive attitudes, teachers should bring them to lessons and use them. The similar suggestion was possible to find out in other studies e.g. Weng et al (2019).

Teachers should try to present schoolwork as close stuff which is interconnect with their everyday life. Another way how to develop positive attitudes toward biology can be using modern technologies during school education. Significant difference was detected between boys and girls and between rural students and urban students. Teachers should systematically work on balancing these differencing and raising attitudes of weaker groups. The teachers could use the inquiry-based methods of teaching. Many studies quoted, that this method is very effective in the understating of the curriculum and also it can be a very important thing to improve attitudes toward biology (Aktamis, Higde \& Ozden 2016; Tessie, 2010; Veloo, Perumal \& Vikneswary 2013). The inquiry-based methods of teaching is approaching the curriculum of biology for students and they have got a direct contact with many biological phenomenon and it can improve the attitudes toward biology (Orazem \& Tomazic 2018; Tomazic \& Sorgo 2017; Torkar et al. 2010). Also the using of innovative teaching methods like active-learning pedagogies, consistent formative assessment or cooperative group could lead to improving of attitudes toward biology. These methods were mentioned as effective in some studies like Connell, Donovan and Chambers (2016) and Taraban et al. (2007).

Other possibility how to improve students' attitudes toward biology is to incorporate the elements of informal learning. Informal science learning experiences such as doing science activities at home or going to out-of school programmes/clubs, visiting a science museum, and playing in nature are essential to advance students' science abilities and attitude (Henriksen, Jensen \& Sjaastad 2015; Lin \& Schunn 2016). On the other side, the application of informal learning activities should not be oversized, as Yoon et al. (2013) mentioned the excessive incorporation of informal learning activities could lead into decreasing of attitudes toward subject, where informal learning was applicate.

Considering current state of literature and results of this study realisation of similar researches are demanded. One of the possible important researches would be the focus on the examining of negative factors, which could create barriers in the improving of attitudes. This study tried to fill empty place in this field of research. There are still a lot of themes which should be acquired in depth. 


\section{ACKNOWLEDGEMENTS}

The work is performed according to the Russian Government Program of Competitive Growth of Kazan Federal University.

\section{REFERENCES}

Aktamis, H., Higde, E., \& Ozden, B. (2016). Effects of the inquiry-based learning method on students' achievement, science process skills and attitudes towards science: A meta-analysis science. Journal of Turkish Science Education, 13(4), 248-261.

Babu, R., \& Govindharajan, G. (2014). Students' attitude towards the study of biology in relation to their study habits. International Journal of Teacher Educational Research, 3(3), 47-52.

Baker, D., \& Leary, R. (1995). Letting girls speak out about science. Journal of Research in Science Teaching, 32(1), 327. https://doi.org/10.1002/tea.3660320104

Cipkova, E., Karolcik, S., Dudova, N., \& Nagyova, S. (2018). What is the students' interest in biology after the biology curriculum modification? The Curriculum Journal, 29(3), 370-386. https:/ / doi.org/10.1080/09585176.2017.1406811

Connell, G. L., Donovan, D. A., \& Chambers, T. G. (2016). Increasing the use of student-centered pedagogies from moderate to high improves student learning and attitudes about biology. CBE Life Sciences Education, 15(1), 1-15. https:/ / doi.org/10.1187/cbe.15-03-0062

Ekici, G., \& Hevedanli, M. (2010). Analyzing high school students' attitudes towards biology course in different variables. Journal of Turkish Science Education, 7(4), 97-109.

Gardner, G. E., Bonner, J., Landin, J., Ferzli, M., \& Shea, D. (2016). Nonmajors' shifts in attitudes \& perceptions of biology \& biologists following an active-learning course: An exploratory study. The American Biology Teacher, 78(1), 43-48. https:// doi.org/10.1525/abt.2016.78.1.43

Hansen, M. J., \& Birol, G. (2014). Longitudinal study of student attitudes in a biology program. CBE Life Sciences Education, 13(2), 331-337. https:/ / doi.org/10.1187/cbe.13-06-0124

Henriksen, E. K., Jensen, F., \& Sjaastad, J. (2015). The role of out-of-school experiences and targeted recruitment efforts in Norwegian science and technology Students' educational choice. International Journal of Science Education, 5(3), 203-222.

Hussaini, I., Foong, L. M., \& Kamar, Y (2015). Attitudes of secondary school students towards biology as a school subject in Birnin kebbi Metropolis, Nigeria. International Journal of Research E Review, 2(10), 596-600.

Christidou, V. (2011). Interest, attitudes and images related to science: Combining students' voices with the voices of school Science, teachers, and popular science. International Journal of Environmental E Science Education, 6(2), 141-159.

Ihuoma, I. M. (2017). A comparative study of urban and rural students' attitude to chemistry at introductory level in Ibadan, Oyo State, Nigeria. Journal of Scientific Research and Studies, 4(7), 165-170.

Jones, M. G., Howe, A., \& Rua, M. J. (2000). Gender differences in students' experiences, interests, and attitudes toward science and scientists. Science Education, 84(2), 180-192. https://doi.org/10.1002/(SICI)1098237X(200003)84:2<180::AID-SCE3>3.0.CO;2-X

Kara, Y., \& Yeksilyurt, S. (2008). Comparing the impacts of tutorial and edutainment software programs on students' achievements, misconceptions, and attitudes towards biology. Journal of Science Education and Technology, 17(1), 32-41. https:/ / doi.org/10.1007/s10956-007-9077-z

Lin, P. Y., \& Schunn, C. D. (2016). The dimensions and impact of informal science learning experiences on middle schoolers' attitudes and abilities in science. International Journal of Science Education, 38(17), 2551-2572. https:/ / doi.org/10.1080/09500693.2016.1251631

Movahedzadeh, F. (2011). Improving students' attitude toward science through blended learning. Science Education $\mathcal{E}$ Civic Engagement -An International Journal, 3(2), 13-19.

Nunnally, J. C. (1978). Psychometric theory (2nd ed.). New York: McGraw-Hill.

Orazem, V., \& Tomazic, I. (2018). The vocational upper secondary schools students' knowledge and their attitudes toward wolves. Journal of Baltic Science Education, 17(6), 918-934. https:/ / doi.org/10.33225/jbse/18.17.918

Partin, M. L. et al. (2011). Yes I Can: The contributions of motivation and attitudes on course performance among biology nonmajors. Journal of College Science Teaching, 40(6), 86-95.

Partin, M. L., \& Haney, J. J. (2012). The CLEM model: Path analysis of the mediating effects of attitudes and motivational beliefs on the relationship between perceived learning environment and course performance 
in an undergraduate non-major biology course. Learning Environments Research, 15(1), 103-123. https:/ / doi.org/10.1007/s10984-012-9102-x

Prokop, P., Prokop, M., \& Tunnicliffe, S. D. (2007). Is biology boring? Student attitudes toward biology. Journal of Biological Education, 42(1), 36-39. https:/ / doi.org/10.1080/00219266.2007.9656105

Prokop, P., Tuncer, G., \& Chuda, J. (2007). Slovakian students' attitudes toward biology. Eurasia Journal of Mathematics, Science \& Technology Education, 3(4), 287-295. https:/ / doi.org/10.12973/ ejmste/75409

Rogers, W. D., \& Ford, R. (1997). Factors that affect student attitude toward biology. Bioscene. Journal of College Biology Teaching, 23(2), 3-6.

Sadler, T. D. (2009). Situated learning in science education: socio-scientific issues as contexts for practice. Studies in Science Education, 45(1), 1-42. https:/ / doi.org/10.1080/03057260802681839

Stuckey, M., Hofstein, A., Mamlok-Naaman, R., \& Eilks, I. (2013). The meaning of 'relevance' in science education and its implications for the science curriculum. Studies in Science Education, 49(1), 1-34. https:// doi.org/10.1080/03057267.2013.802463

Taraban, R., Box, C., Myers, R., Pollard, R., \& Bowen, C. W. (2007). Effects of active-learning experiences on achievement, attitudes, and behaviors in high school biology. Journal of Research in Science Teaching, 44(7), 960-979. https:// doi.org/10.1002/tea.20183

Tessier, J. (2010). An inquiry-based biology laboratory improves preservice elementary teachers' attitudes about science. Journal of College Science Teaching, 39(6), 84-90.

Tomazic, I., \& Sorgo, A. (2017). Factors affecting students' attitudes toward toads. Eurasia Journal of Mathematics Science and Technology Education, 13(6), 2505-2528. https:/ / doi.org/10.12973/eurasia.2017.01237a

Torkar, G., Mohar, P., Gregorc, T., Nekrep, I., \& Adamic, M. H. (2010). The conservation knowledge and attitudes of teenagers in Slovenia toward the Eurasian Otter. International Journal of Environmental E Science Education, 5(3), 341-352.

Trumper, R. (2006). Factors affecting junior high school students' interest in biology. Science Education International, 17(1), 31-48.

Uitto, A. (2014). Interest, attitudes and self-efficacy beliefs explaining upper-secondary school students' orientation towards biology-related careers. International Journal of Science and Mathematics Education, 12(6), 1425-1444. https:/ / doi.org/10.1007/s10763-014-9516-2

Usak, M., Erdogan, M., Prokop, P., \& Ozel, M. (2009a). High school and university students' knowledge and attitudes regarding biotechnology. Biochemistry and Molecular Biology Education, 37(2), 123-130. https://doi.org/10.1002/bmb.20267

Usak, M., Prokop, P., Mustafa, O., Ozel, M., Bilen, K., \& Erdogan, M. (2009b). Turkish university students' attitudes toward biology: the effects of gender and enrolment in biology classes. Journal of Baltic Science Education, $8(2), 88-96$.

Velicer, W. F., \& Fava, J. L. (1998). Effects of variable and subject sampling on factor pattern recovery. Psychological Methods, 3(2), 231-251. https:/ / doi.org/10.1037/1082-989X.3.2.231

Veloo, A., Perumal, S., \& Vikneswary, R. (2013). Inquiry-based instruction, students' attitudes and teachers' support towards science achievement in rural primary schools. Procedia - Social and Behavioral Sciences, 93, 65-69. https:/ / doi.org/10.1016/j.sbspro.2013.09.153

Weng, F., Ho, H.-J., Yang, R.-J., \& Weng, C.-H. (2019). The influence of learning style on learning attitude with multimedia teaching materials. Eurasia Journal of Mathematics Science and Technology Education, 15(1), 1-9.

Yoon, S. A., Elinich, K., Wang, J., van Schooneveld, J. B., \& Anderson, E. (2013). Scaffolding informal learning in science museums: How much is too much? Science Education, 97(6), 848-877. https:/ / doi.org/10.1002/sce.21079

Zeidan, A. H. (2010). The relationship between grade 11 Palestinian attitudes toward biology and their perceptions of the biology learning environment. International Journal of Science and Mathematics Education, 8(5), 783-800. https:/ / doi.org/10.1007/s10763-009-9185-8

Zeidan, A. H., \& Jayoshi, M. D. (2015). Science process skills and attitudes toward science among Palestinian secondary school students. World Journal of Education, 5(1), 13-24.

\section{http://www.ejmste.com}

